\title{
SIMULATION OF THE EFFECTS OF HYPOTHETICAL RESIDENTIAL DEVELOPMENT ON WATER LEVELS IN GRABER POND, MIDDLETON, WISCONSIN
}

By Leo B. House

\section{U.S. GEOLOGICAL SURVEY}

Water-Resources Investigations Report 92-4029

Prepared in cooperation with the CITY OF MIDDLETON, WISCONSIN

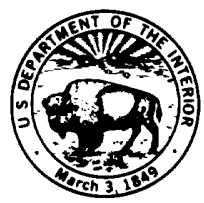

Madison, Wisconsin 


\section{U.S. DEPARTMENT OF THE INTERIOR \\ BRUCE BABBITT, Secretary}

U.S. GEOLOGICAL SURVEY

Dallas L. Peck, Director

District Chief

U.S. Geological Survey

6417 Normandy Lane

Madison, WI 53719
U.S. Geological Survey

Books and Open-File Reports Section

Denver Federal Center, Box 25425

Denver, CO 80225 


\section{CONTENTS}

\section{Page}

Abstract $\ldots \ldots \ldots \ldots \ldots \ldots \ldots \ldots \ldots \ldots \ldots \ldots \ldots \ldots \ldots \ldots \ldots \ldots \ldots$

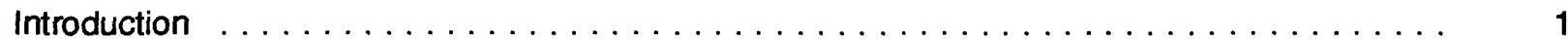

Simulation of the effects of hypothetical residential development $\ldots \ldots \ldots \ldots \ldots \ldots \ldots \ldots$

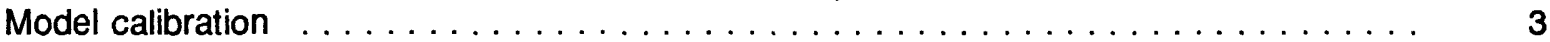

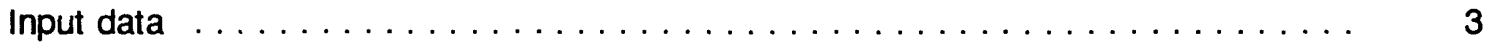

Model sensitivity and uncertainty $\ldots \ldots \ldots \ldots \ldots \ldots \ldots \ldots \ldots \ldots \ldots \ldots \ldots$

Comparison of runoff volume and stage for existing and fully developed watershed

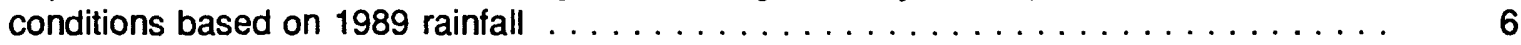

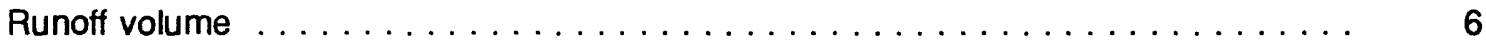

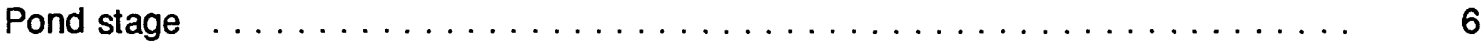

Comparison of runoff and pond-overflow volume for existing and fully developed

watershed conditions for the 100 -year storm $\ldots \ldots \ldots \ldots \ldots \ldots \ldots \ldots \ldots$

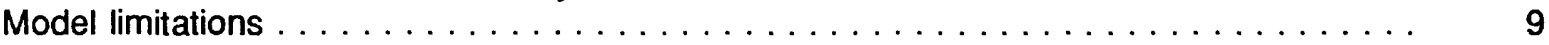

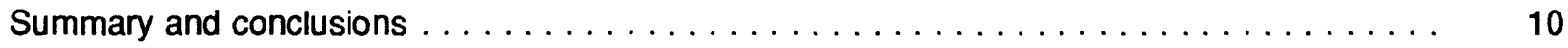

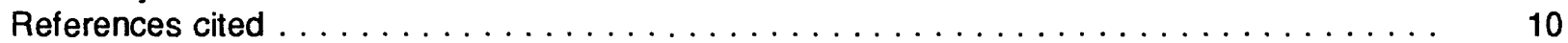

\section{ILLUSTRATIONS}

Figure 1. Map showing location of Graber Pond and watershed ............ 2

2. Graph showing simulated and recorded stage of Graber Pond,

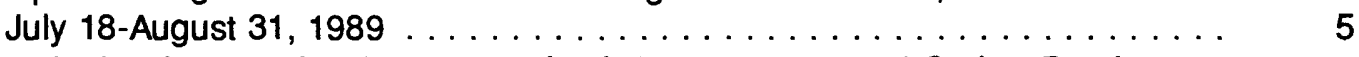

3. Graph showing postdevelopment and existing 1989 stage of Graber Pond, July 18-August 31, 1989

\section{TABLES}

Table 1. Daily rainfall and evaporation, July 18 -August $31,1989 \ldots \ldots \ldots \ldots$

2. Simulated postdevelopment and existing water budgets,

July 18-August 31, 1989

3. Simulated responses of Graber Pond to the 100 -year, 24 -hour-duration rainfall 


\section{CONVERSION FACTORS AND VERTICAL DATUM}

$\begin{array}{lcl}\text { Multiply } & \text { By } & \text { To obtain } \\ \text { inch (in.) } & 25.4 & \text { millimeter } \\ \text { inch per day (in/d) } & 25.4 & \text { millimeter per day } \\ \text { foot (ft) } & 0.3048 & \text { meter } \\ \text { acre } & 0.405 & \text { hectare } \\ \text { acre-foot (acre-ft) } & 1,233 & \text { cubic meter } \\ \text { square mile (mi') } & 2.59 & \text { square kilometer } \\ \text { gallon (gal) } & 3.7864 & \text { liter } \\ \text { million gallons per day (Mgal/d) } & 0.04381 & \text { cubic meter per second }\end{array}$

Sea level: In this report "sea level" refers to the National Geodetic Vertical Datum of 1929--a geodetic datum derived from a general adjustment of the first-order level nets of the United States and Canada, formerly called Sea Level Datum of 1929. 


\title{
SIMULATION OF THE EFFECTS OF HYPOTHETICAL RESIDENTIAL DEVELOPMENT ON WATER LEVELS \\ IN GRABER POND, MIDDLETON, WISCONSIN
}

\author{
By Leo B. House
}

\begin{abstract}
An investigation of the effects of hypothetical residential development in the Graber Pond watershed was done by the U.S. Geological Survey in cooperation with the city of Middleton. The investigation entailed evaluation of the existing (1989) water budget and water-level conditions for the pond and the water-level conditions expected to result from the hypothetical development that may occur by the year 2000. A water-budget model was calibrated to closely match water levels observed from July 18-August 31, 1989. Water input to the pond during this period was computed to be about 2.58 feet. Of this, about 25 percent ( 0.65 foot) was from direct rainfall on the pond surface, about 19 percent ( 0.50 foot) was from storm runoff, and about 55 percent ( 1.43 feet) was discharge from a nearby manufacturing plant. Simulation of the hypothetical development conditions in the watershed predicts that the average late-summer pond level may rise about 0.7 foot.
\end{abstract}

\section{INTRODUCTION}

Graber Pond is a small pond in a rural basin on the northwestern side of the city of Middleton, Wisconsin (fig. 1). This basin is expected to be developed into a residential neighborhood within the next decade. A cooperative investigation was done by the city of Middleton and the U.S. Geological Survey to determine the hydrologic conditions existing in 1989 and to estimate the effects of future development that may occur by the year 2000. This investigation was limited to determining the volume of storm runoff flowing into and out of the pond and the resultant change in pond stage. The results of this investigation are presented in this report. The methodology used to evaluate water levels is applicable to other small ponds in similar basins. The methods used were developed for a previous study (House, 1984) of three small ponds in Middleton.

Graber Pond (fig. 1) is at the lowest point in a small basin. The watershed, which includes the pond surface, has a drainage area of 384 acres. The normal surface area of the pond is about 13 acres. The maximum possible depth of Graber Pond is about $7 \mathrm{ft}$. Water flows from the pond through an outlet to the east when the stage rises to an elevation greater than $904 \mathrm{ft}$ above sea level (local datum $7.23 \mathrm{ft}$ ). This outlet spills across the basin divide into the Pheasant Branch watershed (not shown in fig. 1).

Two nearby manufacturing plants discharge process water directly into Graber Pond. Both manufacturing plants are adjacent to the southwestern side of the pond. One of the manufacturing plants discharges an average of 0.145 Mgal/d to the pond (Toby Ginder, City of Middleton Public Works Department, oral commun., 1989). The other manufacturing plant discharges less than 10 percent of this amount. The larger discharge is continuous; the smaller is intermittent.

Graber Pond is now a perennial pond. Maps made before the startup of the manufacturing plants show the area of Graber Pond as being much smaller than it is today. Long-time residents have stated that the pond would periodically dry up in the past. The pond did not 


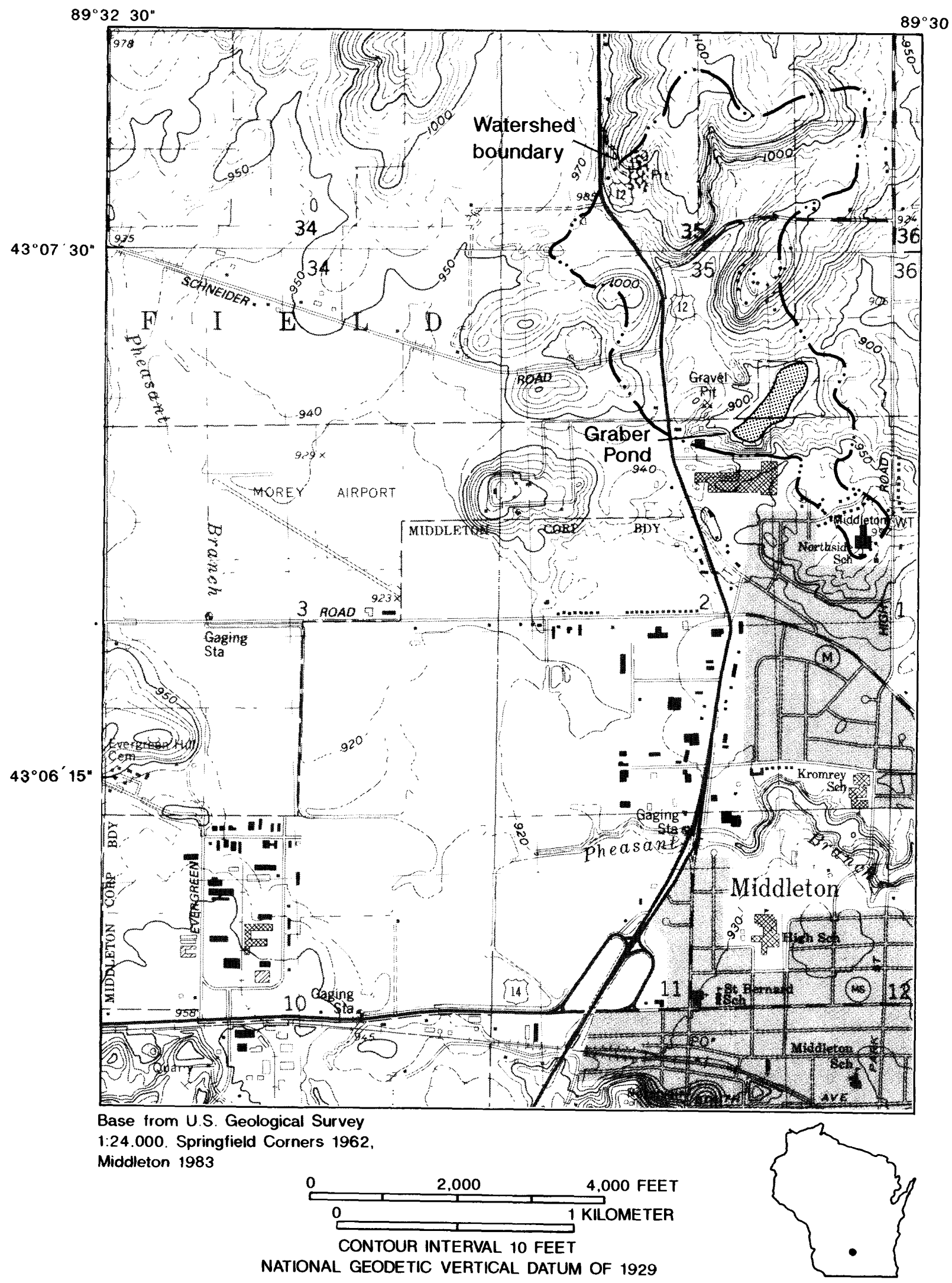

Figure 1. Location of Graber Pond and watershed. 
dry up during the statewide drought of 1988 because of the inflow provided by the manufacturing plants.

The Graber Pond watershed is primarily rural at the present time (1989). Land use is a mix of agriculture, woodland, brushland, and highway corridors. There is some low-density residential development on a hilltop to the north of the pond and some residential development in the extreme southeast corner of the watershed. This residential area is drained by a storm sewer that routes the drainage into the pond. Sanitary sewers convey flow to the regional treatment plant and do not contribute inflow to the pond. The residential areas currently (1989) account for less than 10 percent of the total watershed area.

\section{SIMULATION OF THE EFFECTS OF HYPOTHETICAL RESIDENTIAL DEVELOPMENT}

Daily water levels were simulated for Graber Pond by use of a rainfall-runoff model. The model is based on the U.S. Soil Conservation Service (1986) curve-number approach. A complete description of the methods that were used to develop the model are given in a previous report (House, 1984). The model was calibrated for existing conditions in the Graber Pond watershed, July 18-August 31, 1989.

The calibrated model was used to simulate water levels in Graber Pond for different development and rainfall conditions. Specifically, the calibrated model was used to evaluate the effects of the expected development on runoff volume to the pond and resultant pond stage. The approach used for this evaluation was to--

1. Simulate the effects of fully developed watershed conditions for the observed 1989 rainfall record, and

2. simulate the effects of the 100-year, 24hour-duration rainfall for existing 1989 and fully developed watershed conditions.

\section{Model Calibration}

The model was calibrated to match the stage at Graber Pond during the summer of 1989. Input data for the model were obtained from several sources, as described in the following section.

\section{Input Data}

Daily rainfall data were collected by use of a recording rainfall gage at the pond. Daily evaporation was computed from the Lamoreaux equation (Lamoreaux, 1962). The Lamoreaux equation requires average air temperature, average vapor and saturation vapor pressure, solar radiation, and wind speed as input. The required meteorologic data were obtained from the Wisconsin State Climatologist (National Oceanic and Atmospheric Administration, 1989). The daily rainfall and evaporation data are presented in table 1.

The drainage area contributing runoff to the pond was determined from U.S. Geological Survey $7 \frac{1}{2} 2$-minute topographic quadrangle maps of the area. Drainage divides were verified by inspection. The elevation-area bathymetric data for the pond were determined from 2-foot contour maps provided by the city of Middleton.

\section{Model Sensitivity and Uncertainty}

The long-term ( 1 week or longer) simulation of water levels in the pond is most sensitive to the parameters used in the ground-water infiltration equation. The form of the equation used in the Graber Pond model is

$$
\mathrm{GWI}=[(\text { Stage }-\mathrm{A}) \times \mathrm{B}]+\mathrm{C},
$$

where GWI is ground-water infiltration rate (inches per day),

Stage is pond stage at start of the day (midnight), and

$A, B$, and $C$ are model-calibration parameters. 
Table 1.--Daily rainfall and evaporation, July 18-August 31, 1989

$$
\text { [in., inch; --, no rain] }
$$

\begin{tabular}{|c|c|c|c|c|c|}
\hline Date & $\begin{array}{l}\text { Rainfall } \\
\text { (in.) }\end{array}$ & $\begin{array}{l}\text { Evaporation } \\
\text { (in.) }\end{array}$ & Date & $\begin{array}{l}\text { Rainfall } \\
\text { (in.) }\end{array}$ & $\begin{array}{l}\text { Evaporation } \\
\text { (in.) }\end{array}$ \\
\hline $07 / 18$ & 0.48 & 0.11 & $08 / 10$ & 0.01 & 0.17 \\
\hline $07 / 19$ & .89 & .02 & $08 / 11$ & .00 & .08 \\
\hline $07 / 20$ & .01 & .20 & $08 / 12$ & -- & .20 \\
\hline $07 / 21$ & .26 & .06 & $08 / 13$ & .06 & .07 \\
\hline $07 / 22$ & -- & .09 & $08 / 14$ & .34 & .09 \\
\hline $07 / 23$ & .01 & .18 & $08 / 15$ & -- & .04 \\
\hline $07 / 24$ & .02 & .14 & $08 / 16$ & .01 & .18 \\
\hline $07 / 25$ & -- & .09 & $08 / 17$ & -- & .17 \\
\hline $07 / 26$ & .01 & .18 & $08 / 18$ & -- & .19 \\
\hline $07 / 27$ & -- & .24 & $08 / 19$ & .30 & .17 \\
\hline $07 / 28$ & -- & .16 & $08 / 20$ & -- & .16 \\
\hline $07 / 29$ & .87 & .03 & $08 / 21$ & .01 & .20 \\
\hline $07 / 30$ & .15 & .05 & $08 / 22$ & .66 & .18 \\
\hline $07 / 31$ & .01 & .11 & $08 / 23$ & -- & .02 \\
\hline $08 / 01$ & -- & .18 & $08 / 24$ & -- & .16 \\
\hline 08/02 & -- & .23 & $08 / 25$ & -- & .11 \\
\hline $08 / 03$ & -- & .18 & $08 / 26$ & .13 & .04 \\
\hline $08 / 04$ & -- & .19 & $08 / 27$ & -- & .16 \\
\hline 08/05 & .75 & .21 & $08 / 28$ & 2.02 & .06 \\
\hline 08/06 & -- & .11 & $08 / 29$ & -- & .14 \\
\hline 08/07 & -- & .19 & $08 / 30$ & -- & .17 \\
\hline 08/08 & -- & .19 & $08 / 31$ & .83 & .08 \\
\hline 08/09 & -- & .17 & & & \\
\hline
\end{tabular}

The values of $A, B$, and $C$ were determined by calibrating the model to simulate observed water levels for the period July 18-August 31, 1989. The resulting values of these parameters are as follows:

$$
\begin{aligned}
& A=4.15 \mathrm{ft} \\
& B=0.5(\mathrm{in} / \mathrm{d}) / \mathrm{ft} \\
& C=0.38 \mathrm{in} / \mathrm{d}
\end{aligned}
$$

The value of $A$ is related to the elevation of the local water table below the pond and varies with the time of year. $B$ is related to the rate at which the pond level will return to an equilibrium state after a sudden increase or decrease in stage, and $C$ reflects the long-term steady-state infiltration rate.
The value of $A$ is the most uncertain of the infiltration parameters. It was not possible to use a constant value to simulate the entire May through November period; however, close agreement between simulated and observed water levels was possible for the period July 18-August 31,1989 , for which a constant value for $A$ was used (fig. 2).

The short-term ( 1 to 2 days) simulation of storm response is most sensitive to the U.S. Soil Conservation Service (SCS) curve number (U.S. Department of Agriculture, 1986) for the watershed and the percentage of impervious area in the watershed. The curve number reflects the soil type, vegetative cover, and moisture conditions of the soil. Because the cover and moisture 


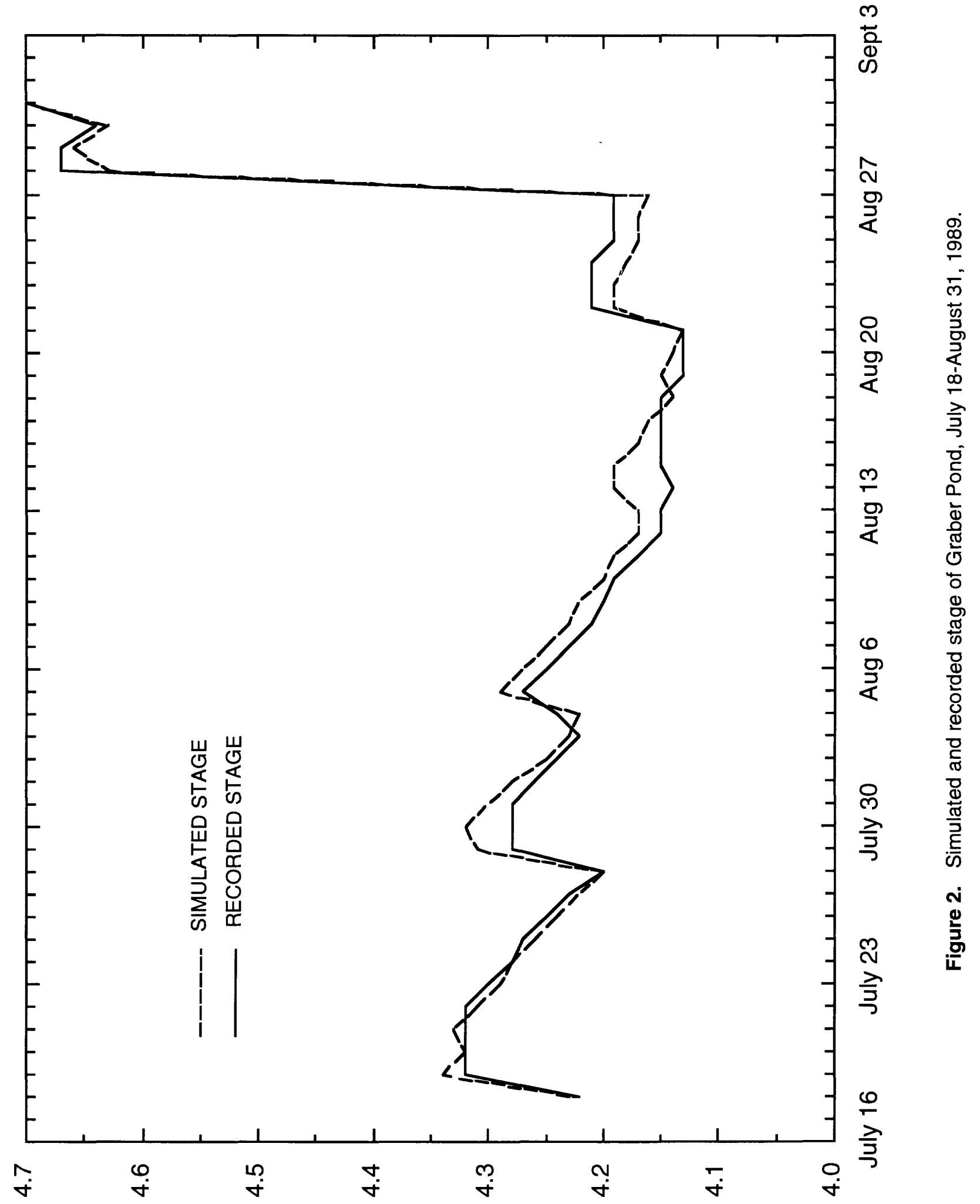

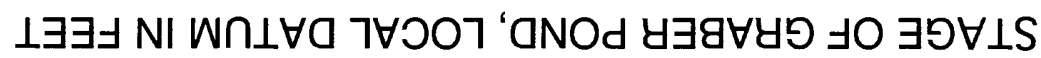


conditions are constantly changing, it was not possible to simulate the entire open-water period (May through November) with a constant curve number. The percentage of impervious area refers to the hydraulically connected impervious area within the watershed. This area typically includes guttered streets and rooftops that drain to the street.

The rainfall response of the pond stage was adequately simulated by use of a modified SCScurve-number approach. A curve number of 62 and a 4-percent impervious basin were used to simulate existing 1989 conditions (fig. 2). A detention depth of 0.35 in. was used to reflect storage in the impervious areas of the basin. Any excess rainfall above 0.35 in. in 1 day became runoff to the pond. The value of 0.35 in. was used to be consistent with the previous study of ponds in the Middleton area (House, 1984). This value was found to give the best model calibration in the previous study. The 0.35-in. value probably reflects ponding of water on streets and storage in the storm sewers.

Simulated runoff from the pervious area occurred when the daily rainfall depth exceeded the "initial abstraction" depth determined from the SCS curve number and the equation

$$
I A=0.2 \times S,
$$

where IA is Initial abstraction (inches), and

$$
S \text { is [1000/Curve Number] - } 10 .
$$

\section{Comparison of Runoff Volume and Stage for Existing and Fully Developed Watershed Conditions Based on 1989 Rainfall}

The calibrated model was used to simulate pond stage and runoff volumes from the watershed. Simulations were made for existing (1989) conditions and a hypothetical fully urbanized watershed. The SCS curve number and percent impervious area for each condition is given in table 2. The comparison of the results of these simulations are presented in the following sections.

The use of an SCS curve number of 82 for the hypothetical development conditions is very conservative, and probably represents the worstcase condition for a late-summer period. Such a curve number is representative of antecedent moisture conditions for above-average rainfall during the period of simulation. The 7.5 percent impervious area reflects low-density residential development.

\section{Runoff Volume}

The total runoff volume for pervious and impervious areas during July 18-August 31, 1989, for the existing conditions is $0.5 \mathrm{ft}$ (expressed as depth spread over the pond-surface area). This runoff volume accounts for 19 percent of the total inflow to the pond (table 2). The total runoff volume for the fully developed conditions, $2.63 \mathrm{ft}$, accounts for 57 percent of the total inflow volume. Precipitation and industrial discharge to the pond were the same for both conditions. The industrial discharge depth shown in table 2 is slightly different between conditions because of the change in the average pond area. There is a net increase in runoff volume of about $2.1 \mathrm{ft}$ (depth over pond area) for the simulated fully developed watershed conditions.

\section{Pond Stage}

The simulated pond stage for the fully developed watershed conditions is shown in figure 3 . The fully developed conditions were simulated with use of a SCS curve number of 82 and an impervious area of 7.5 percent. No other calibrated model parameters were changed. The curve number and percentage of impervious area are consistent with the values used previously to evaluate other urbanizing watersheds in Middleton (House, 1984). The simulation of the fully developed conditions indicates peak pond stage will increase an average of about $0.7 \mathrm{ft}$ above that for the existing 1989 conditions for most of the simulation period (July 18-August 31, 1989). 
Table 2.--Simulated postdevelopment and existing water budgets, July 18-August 31, 1989

$$
\text { [ft, feet] }
$$

A. Existing 1989 conditions: curve number $=62,4$ percent impervious area

Total inflow $=2.58 \mathrm{ft}$

Direct precipitation on pond surface

Industrial discharge to pond ${ }^{1}$

Impervious area runoff

Pervious area runoff

Total outflow $=2.13 \mathrm{ft}$

Ground-water infiltration

Evaporation

$\begin{array}{ccc} & \begin{array}{c}\text { Depth } \\ \text { (ft) }\end{array} & \begin{array}{c}\text { Percentage } \\ \text { of total }\end{array} \\ & & \\ & 0.65 & 25.2 \\ & 1.43 & 55.4 \\ .32 & 12.4 \\ \text { Total } & \frac{.18}{2.58} & \frac{7.0}{100} \\ & & \\ \text { Total } & 1.62 & 76.1 \\ & \frac{.51}{2.13} & \frac{23.9}{100}\end{array}$

Total inflow - outflow $=0.45 \mathrm{ft}$ rise in pond stage.

B. Fully developed conditions: curve number $=82,7.5$ percent impervious area

Total inflow $=4.60 \mathrm{ft}$

Direct precipitation on pond surface

Industrial discharge to pond'

Impervious area runoff

Pervious area runoff

Total outflow $=3.15 \mathrm{ft}$

Ground-water infiltration

Evaporation

\begin{tabular}{|c|c|c|}
\hline & $\begin{array}{l}\text { Depth } \\
\text { (ft) }\end{array}$ & $\begin{array}{c}\text { Percentage } \\
\text { of total }\end{array}$ \\
\hline & .65 & 14.1 \\
\hline & 1.32 & 28.7 \\
\hline & .57 & 12.4 \\
\hline & $\underline{2.06}$ & 44.8 \\
\hline Total & 4.60 & 100 \\
\hline
\end{tabular}

Total
83.8

$\frac{16.2}{100}$

Total inflow - outflow $=1.45 \mathrm{ft}$ rise in pond stage.

${ }^{1}$ The difference shown between conditions is because of a change in average pond area. Total inflow volume is the same for both conditions. 


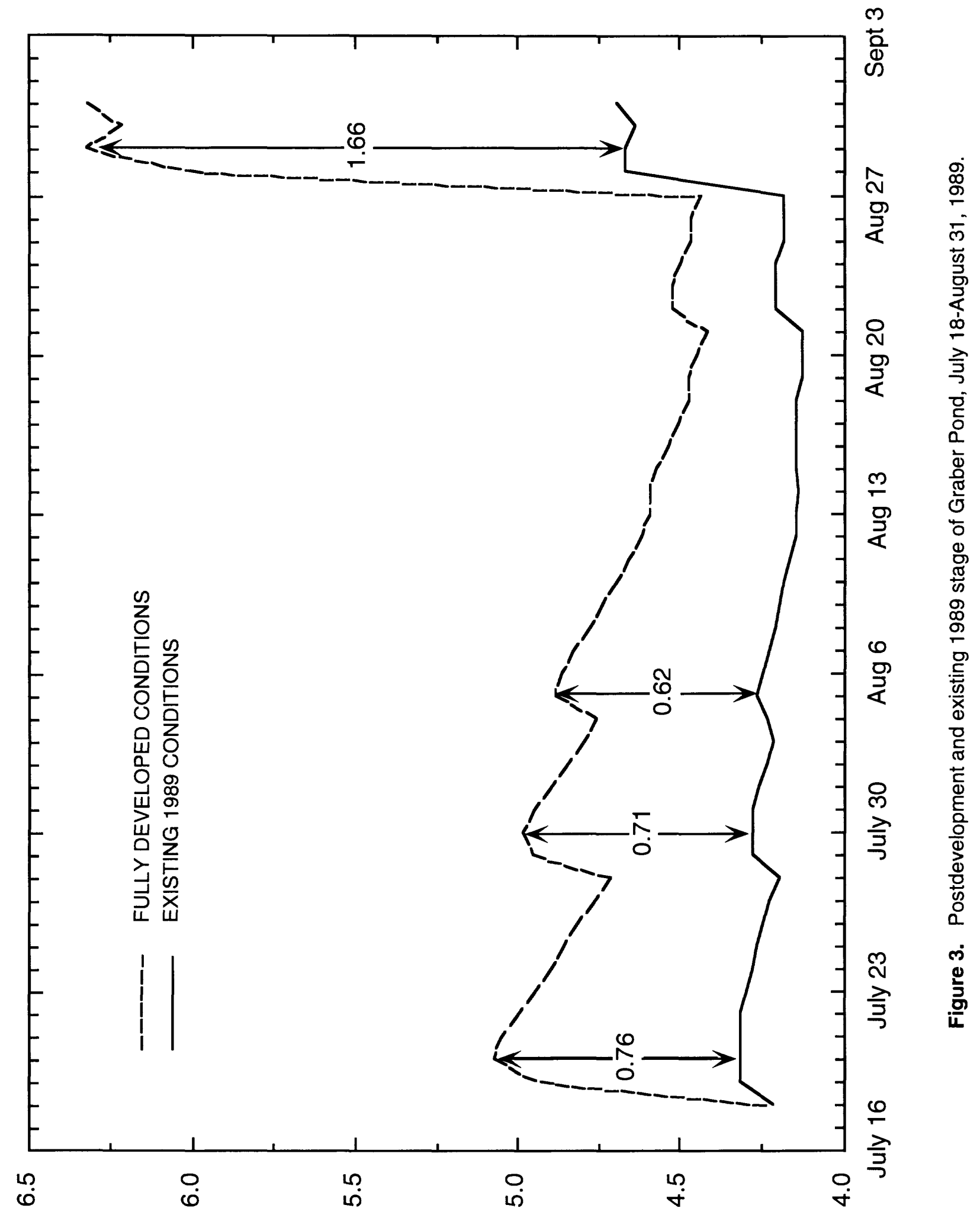

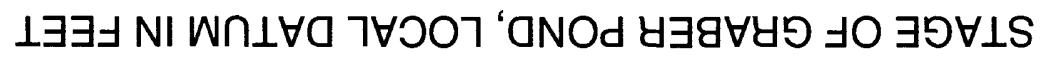


Comparison of Runoff and Pond-

Overflow Volume for Existing and

Fully Developed Watershed

\section{Conditions for the 100-Year Storm}

The calibrated model was used to simulate the effects of the 100-year, 24-hour-duration storm. This storm rainfall depth was estimated to be 5.95 in. from a rainfall-frequency atlas (U.S. Department of Commerce, 1961). The results of this simulation are presented in table 3.

In response to a 100-year, 24-hour storm, the pond will overflow across the basin divide into the Pheasant Branch watershed under existing and fully developed conditions. The pond spills across the basin divide at an elevation in excess of $904 \mathrm{ft}$ above sea level (7.23 ft gage datum); however, the overflow volume for the existing conditions is 70 acre-ft, and that for the fully developed condition is 177 acre-ft (table 3 ). This change in outflow volume is an increase of greater than 150 percent.

\section{Model Limitations}

The curve-number method used in the model was developed by the SCS for simulation of discrete storms, and not for simulation of continuous daily runoff as was done in this study. It was not possible to use a constant curve number to calibrate the watershed response to rainfall in both spring and summer.

Table 3.--Simulated responses of Graber Pond to the 100-year, 24-hour-duration rainfall

$$
\text { [ft, feet] }
$$

A. Existing conditions: curve number $=62,4$ percent impervious area

Runoff volume (depth over pond surface)

\begin{tabular}{|c|c|c|}
\hline & $\begin{array}{l}\text { Runoff } \\
\text { (ft) }\end{array}$ & $\begin{array}{l}\text { Percentage } \\
\text { of total }\end{array}$ \\
\hline & 3.99 & 89.9 \\
\hline tal & $\frac{.45}{4.44}$ & $\frac{10.1}{100}$ \\
\hline
\end{tabular}

Pond overflow volume for the 100 -year storm event is 70 acre-feet.

B. Fully developed conditions: curve number $=82,7.5$ percent impervious area

\begin{tabular}{cccc} 
Runoff volume (depth over pond surface) & $\begin{array}{c}\text { Runoff } \\
\text { (ft) }\end{array}$ & $\begin{array}{c}\text { Percentage } \\
\text { of total }\end{array}$ \\
\cline { 2 - 2 } $\begin{array}{c}\text { Pervious area runoff } \\
\text { Impervious area runoff }\end{array}$ & 7.04 & 89.7 \\
& Total & $\frac{.81}{7.85}$ & $\frac{10.3}{100}$
\end{tabular}

Pond overflow volume for the 100 -year storm event is 177 acre-feet. 
It should also be noted that the infiltration parameters were determined for a range in pond stage of about $0.5 \mathrm{ft}$. The extrapolation of infiltration rates to changes in pond stage of about $3 \mathrm{ft}$ is probably inaccurate. However, the infiltration rate is not important in simulation of the change in pond stage caused by a short-term rainfall.

The model does not account for any runoff retention or detention basins that may be incorporated into the fully developed watersheds drainage system. Such basins could serve to reduce the rate and to a lesser extent the volume of runoff entering the pond. The assumed percent impervious area in the fully developed watershed may also be inaccurate, as may be the assumed curve number, because the nature of the development is unknown.

\section{SUMMARY AND CONCLUSIONS}

A water-budget simulation model was used to evaluate the runoff volume and resultant pond stage in the Graber Pond watershed. The evaluation was based on the existing (1989) and hypothetical full residential development, which may occur by the year 2000 .

The simulation model, which was similar to that used in a previous study of other urban pond watersheds in Middleton, was calibrated to match recorded pond stage for the period July 18August 31, 1989. Water input to the pond during this period was determined to be about $2.58 \mathrm{ft}$ (expressed as depth over the pond surface area). Of this, about 25 percent $(0.65 \mathrm{ft})$ was from direct rainfall on the pond surface, about 19 percent $(0.50 \mathrm{ft})$ was from storm runoff, and about 55 percent $(1.43 \mathrm{ft}$ ) was discharge from a nearby manufacturing plant. The calibrated model was used to compute the water budget for a hypo- thetical fully developed condition in the watershed. The simulation of hypothetical development in the watershed predicts that the total water input to the pond could increase by about $2 \mathrm{ft}$ for the period simulated, and the average late-summer pond level might rise about $0.7 \mathrm{ft}$.

The model was also used to compute the runoff volume and resultant pond overflows for the 100-year, 24-hour-duration storm. This 100year storm causes the pond to overflow into the Pheasant Branch watershed for both sets of development conditions. The volume of pond overflow for the existing 1989 condition was simulated to be 70 acre-ft, and the volume of pond overflow for the hypothetical condition was 177 acre-ft.

\section{REFERENCES CITED}

House, L.B., 1984, Effects of urbanization on three ponds in Middleton, Wisconsin: U.S. Geological Survey Water-Resources Investigations Report 84-4051, 17 p.

Lamoreaux, W.W., 1962, Modem evaporation formulae adopted to computer use: Monthly Weather Review, v. 90, no. 1, p. 26-28.

National Oceanic and Atmospheric Administration, 1989, Local climatological data-Wisconsin monthly summary, Dane County Regional Airport: July-August.

U.S. Department of Agriculture, 1986, Urban hydrology for small watersheds: Soil Conservation Service Technical Release 55.

U.S. Department of Commerce, 1961, Rainfall frequency atlas of the United States: Weather Bureau Technical Paper 40,61 p. 